\title{
STRENGTHENING OF REINFORCED CONCRETE BEAM USING STEEL FIBER AT DIFFERENT DEPTH OF THE BEAM
}

\author{
Prakash Mondal ${ }^{1}$, Dilip Kumar Singha Roy $^{2}$ \\ ${ }^{1}$ Assistant professor, Department of Civil Engineering, Dr. B.C.Roy Engineering College,Durgapur, WestBengal, \\ India \\ ${ }^{2}$ Professor, Department of Civil Engineering, National Institute of Technology Durgapur, WestBengal, India
}

\begin{abstract}
This paper presents the results of an experimental investigation for enhancing the shear and ultimate strength capacities of reinforced concrete $(R C)$ beams using steel fiber at different depths. Ultimate loads, load-deflection curves, cracking and crushing patterns have been compared with those of the RC beams without steel fiber henceforth noted as controlled beam. A total of four sets of experiments each having three concrete beams, one set control beam and three sets with randomly distributed discrete steel fiber at different depths henceforth noted as fiber reinforced concrete (FRC) beam, were performed to determine the most economical structure in the perspective of ultimate strength and shear capacity. From the test results, it was found that incorporation of steel fiber in RC beams have shown to be effective in enhancing the shear strength capacity. It has also been observed that the strength increases with the use of varying depth of steel fiber. Beam strengthened using this scheme has shown $20 \%$ increase in shear strength and ultimate load in comparison to controlled beam.
\end{abstract}

\section{Key Words: Reinforced Concrete Beams, High Strength Concrete, Steel fibers, strengthening}

$* * *$

\section{INTRODUCTION}

During the past 30 years, attempts have been made to enhance strength of reinforced concrete beams by bonding steel fibers to beam in terms of flexural or shear strength. The concrete construction field has shown a growing interest in the advantages of introduction of fiber reinforcement in structural elements. Among the different fibers available, e.g. steel, synthetic, glass, and natural fibers, the steel fiber is probably the most investigated and most commonly used. Fiber reinforcement today is mainly used in many applications such as industrial beam \& floors, overlays, and sprayed concrete, although other application areas exist. Addition of short, discontinuous fibers plays an important role in the improvement of the mechanical properties of concrete. Some of the potential benefits of fibers in concrete are improved crack control and more strength than plain concrete, and the possibility of designing more slender structures. However, the extent of the crack control depends to a large extent on the type and amount of fibers added.

From the durability point of view it is essential to control the cracking process and, moreover, being able to predict crack widths and crack pattern as well as to design a structure that exhibits the desired behaviour. This behaviour of course, depends on a number of different factors such as structural type and size, type of concrete and type of steel fiber and, amount and type of reinforcement, and the casting procedure. In general, to achieve crack control, large amounts of conventional reinforcement are needed, especially in structures where only very small crack widths $(\mathrm{w} \leq 0.1 \mathrm{~mm})$ are allowed. Negative effects from large amounts of reinforcement are that the structural dimensions often need to be larger than what is needed for load bearing capacity in order to make space for all the steel, the labour involvement in placing it, and also difficulties with pouring the concrete paste in tightly placed reinforcement bars of the steel cage. By using fibers in combination with or instead of the conventional reinforcement, these drawbacks may be reduced or even completely avoided.

The use of steel fiber reinforced concrete (SFRC) is, thus, particularly suitable for structures when they are subjected to loads over the serviceability limit state in bending and shear, and when exposed to impact or dynamic forces, as they occur under seismic or cyclic action. However, there is still incomplete knowledge on the design/analysis of fiberreinforced concrete structural members. FRC is a cement based composite material reinforced with discrete, usually randomly distributed, fibers $[1,2]$.The analysis of structural sections requires, as a basic prerequisite, the definition of a suitable stress-strain relationship for each material to relate its behaviour to the structural response. Many stress-strain relationships, in tension and in compression, for FRC materials have been proposed in literature by different authors. In particular, when fibers are added to a concrete mix, fiber characteristics such as their type, shape, aspect ratio $L_{f} / D_{f}$, where $L_{f}$ fiber length and $D_{f}$ fiber diameter, play an important role in modifying the behavior of the material [3]. Although it has been found that adding fibers to concrete mainly enhances the post-cracking properties in terms of a more ductile behaviour and reduced crack widths, it still remains to show that these enhanced mechanical 
properties can be predicted with reasonable accuracy and that they can be incorporated into design methods. Presently, a number of laboratory experiments on mechanical property of SFRC have been done. Pereira et. al. [4] presented an experimental research on the steel fiberreinforced concrete and numerical simulation of punching test. Using notched cylindrical specimens, fracture energy of steel fiber reinforced concrete was measured, and a new trilinear cohesive law was proposed by Kazemi et. al.[5]. By testing the deformational behavior of conventionally reinforced steel fiber concrete beams in pure bending, Dwarakanath and Nagaraj[6] gave an economical and efficient use of steel fibers. The study results given by Thomas and Ramaswamy[7] indicated that the fiber and matrix interaction contributed significantly to enhancement of mechanical properties caused by the introduction of fibers. Numerical analysis and field test on performance of steel fiber reinforced concrete segment in subway tunnel were described by Zhu [8].Bending and uniaxial tensile tests on hybrid fiber reinforced concretes combining fibers with different geometry and material were presented by Sorelli et al.[9]. However, these investigations were mostly based on the Macro-phenomena of the specimen failure. The general laboratory experiments couldn't give a thorough cognition to the deformation and destruction process of SFRC, particularly, in reflecting the basic features of deformation localization and stress redistribution. Hence, an attempt has been made in the present study to carry out a set of experiments on the SFRC specimens using discrete steel fibers randomly distributed at different depths of the beam. Moreover, study has been made on the load-deflection behaviour of layered steel fiber reinforced concrete beam which is important in view of its ductility aspect, the flexural strength and mode of failure.

\subsection{OBJECTIVE}

1. The main objective of present work is to study the behaviour of reinforced concrete beams strengthened with steel fiber.

2. To study the effect of steel fiber strengthening of RC Beams on ultimate load carrying capacity and failure pattern.

3. Comparative study of the crack pattern and crushing behavior between controlled beam and strengthened FRC beams.

\subsection{SCIENTIFIC APPROACH}

This paper provides the test data related to behaviour of strengthening of RC beams using steel fiber. These data are useful for developing constitutive models for shear response of structural elements where high strength concrete is used. The experiments have been conducted based on two-point beam bending to investigate structural behaviour.

\section{EXPERIMENTAL PROGRAMME}

Twelve reinforced concrete beams were cast and tested under two point loading, using fiber at three deferent depths for nine beams and three control beams. All specimens were design according to IS: 456-2000 with identical size of 1450x150x200 mm. All beams have identical reinforcement details including longitudinal reinforcement in the form of $12 \mathrm{~mm}$ diameter HYSD bar and stirrups reinforcement of 8 $\mathrm{mm}$ diameter at $130 \mathrm{~mm}$ spacing center to center as shown in Fig. 1 with specimen details. The investigated beams have been divided into four sets with and without the use of fiber different depth of the beam. All beams were cast using ready mix concrete with compressive strength of $25 \mathrm{~N} / \mathrm{mm}^{2}$. Details of the test specimens of four set with and without the use of fiber at different depths of the RC beam have been presented in Tables 1to 4.
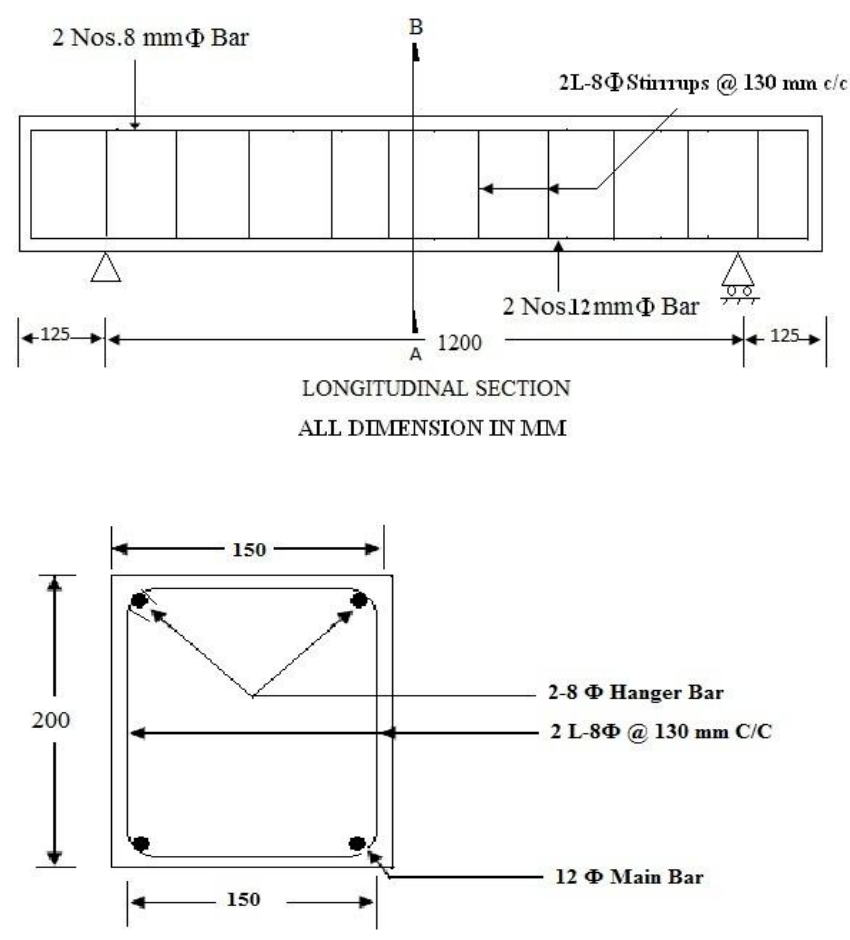

BEAM SECTION A-B

Fig-1: Longitudinal and Cross sections details of RC beams

Table-1: Details of Reinforced Concrete Beam

\begin{tabular}{|c|c|c|c|c|c|}
\hline $\begin{array}{c}\text { Serial } \\
\text { no. }\end{array}$ & $\begin{array}{c}\text { Beam } \\
\text { designation }\end{array}$ & $\begin{array}{c}\text { Beam } \\
\text { Width } \\
(\mathrm{mm})\end{array}$ & $\begin{array}{c}\text { Depth of } \\
\text { Beam(mm) }\end{array}$ & $\begin{array}{c}\text { Length of } \\
\text { beam(mm) }\end{array}$ & $\begin{array}{c}\text { Use } \\
\text { of } \\
\text { Fiber }\end{array}$ \\
\hline SL1 & P/B-1 & 150 & 200 & 1450 & NO \\
\hline SL2 & P/B-2 & 150 & 200 & 1450 & NO \\
\hline SL3 & P/B-3 & 150 & 200 & 1450 & NO \\
\hline
\end{tabular}

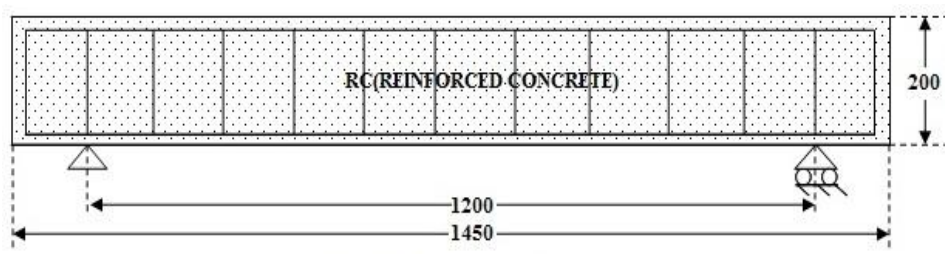

ALL DIMENSION ARE IN MM

Fig-.2: Details of Reinforced Concrete Beam 
Table-2: Details of Fully Fiber Reinforced Concrete Beam

\begin{tabular}{|c|c|c|c|c|c|}
\hline $\begin{array}{c}\text { Serial } \\
\text { no. }\end{array}$ & $\begin{array}{c}\text { Beam } \\
\text { designa } \\
\text { tion }\end{array}$ & $\begin{array}{c}\text { Beam } \\
\text { Width } \\
(\mathrm{mm})\end{array}$ & $\begin{array}{c}\text { Depth } \\
\text { of } \\
\text { Beam } \\
(\mathrm{mm})\end{array}$ & $\begin{array}{c}\text { Length } \\
\text { of } \\
\text { beam } \\
(\mathrm{mm})\end{array}$ & $\begin{array}{c}\text { Use of } \\
\text { Fiber }\end{array}$ \\
\hline SL4 & F/B-1 & 150 & 200 & 1450 & $\begin{array}{c}\text { Full } \\
\text { Depth } \\
\text { of } \\
\text { Beam }\end{array}$ \\
\hline SL5 & F/B-2 & 150 & 200 & 1450 & $\begin{array}{c}\text { Full } \\
\text { Depth } \\
\text { of } \\
\text { Beam }\end{array}$ \\
\hline SL6 & F/B-3 & 150 & 200 & 1450 & $\begin{array}{c}\text { Full } \\
\text { Depth } \\
\text { of } \\
\text { Beam }\end{array}$ \\
\hline
\end{tabular}

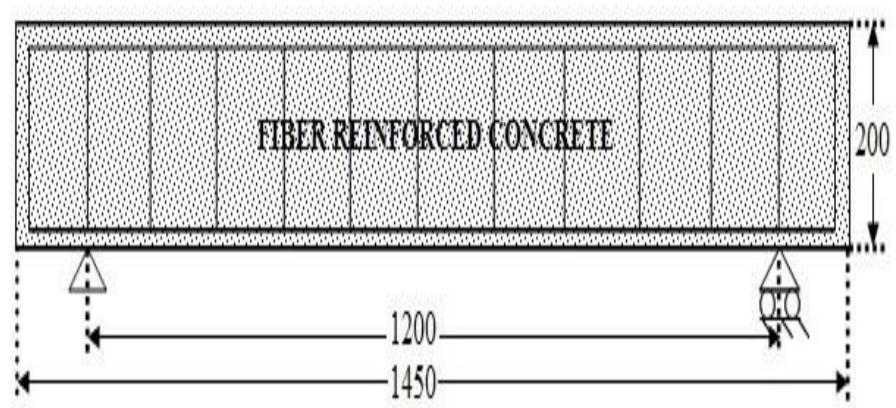

\section{ALLDLENSIONARE INIMI}

Fig.-3: Fiber Reinforced Concrete Beam

Table-3: Details of 0.5 Depth Level of Fiber Reinforced Concrete Beams

\begin{tabular}{|c|c|c|c|c|c|}
\hline $\begin{array}{c}\text { Serial } \\
\text { no. }\end{array}$ & $\begin{array}{c}\text { Beam } \\
\text { designation }\end{array}$ & $\begin{array}{c}\text { Beam } \\
\text { Width } \\
(\mathrm{mm})\end{array}$ & $\begin{array}{c}\text { Depth of } \\
\text { Beam } \\
(\mathrm{mm})\end{array}$ & $\begin{array}{c}\text { Length of } \\
\text { beam } \\
(\mathrm{mm})\end{array}$ & $\begin{array}{c}\text { Use } \\
\text { of } \\
\text { Fiber }\end{array}$ \\
\hline SL7 & $0.5 \mathrm{D}-\mathrm{B}-1$ & 150 & 200 & 1450 & $\begin{array}{c}0.5 \mathrm{~d} \\
\text { Depth } \\
\text { of } \\
\text { Beam }\end{array}$ \\
\hline SL8 & $0.5 \mathrm{D}-\mathrm{B}-2$ & 150 & 200 & 1450 & \begin{tabular}{c}
$0.5 \mathrm{~d}$ \\
Depth \\
of \\
Beam \\
\hline SL9
\end{tabular} \\
\hline & $0.5 \mathrm{D}-\mathrm{B}-3$ & 150 & 200 & 1450 & $\begin{array}{c}0.5 \mathrm{~d} \\
\text { Depth } \\
\text { of } \\
\text { Beam } \\
\end{array}$ \\
\hline
\end{tabular}

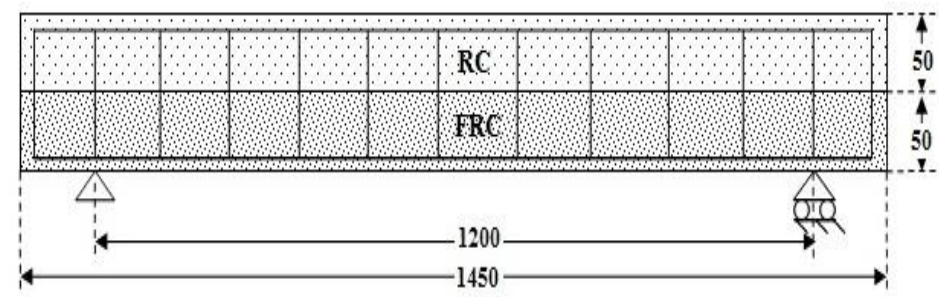

ALL DIIENSION ARE INMM

Fig.-4: Reinforced Concrete Beam with 0.5Depth Level of Fiber

Table-4: Tensile bar depth Level of Fiber Reinforced Concrete Beams

\begin{tabular}{|c|c|c|c|c|c|}
\hline $\begin{array}{c}\text { Serial } \\
\text { no. }\end{array}$ & $\begin{array}{c}\text { Beam } \\
\text { designation } \\
\text { Sidth } \\
(\mathrm{mm})\end{array}$ & $\begin{array}{c}\text { Beam } \\
\text { of } \\
\text { Beam } \\
(\mathrm{mm})\end{array}$ & $\begin{array}{c}\text { Length } \\
\text { of } \\
\text { beam } \\
(\mathrm{mm})\end{array}$ & $\begin{array}{c}\text { Use of } \\
\text { Fiber }\end{array}$ \\
\hline BL.SB(F)- \\
B-1
\end{tabular}

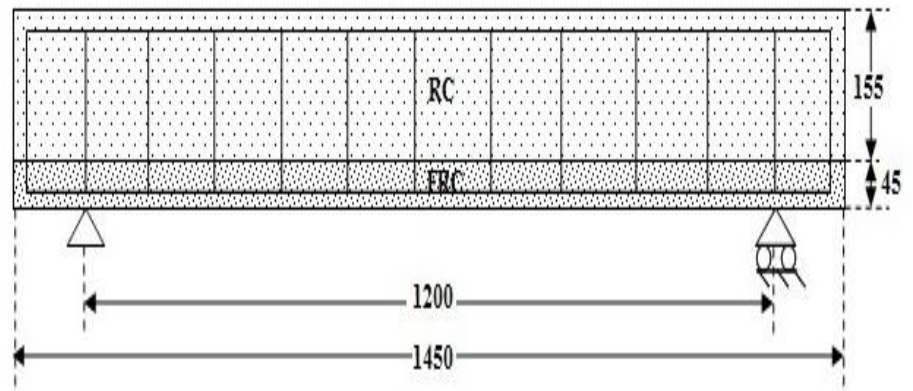

\section{ALL DIENSIONARE INMIM}

Fig.-5: Reinforced Concrete Beam

(Fiber reinforced up to top level of tensile reinforced zone) 
Table-5: Concrete Material Properties

\{IS:456-2000(CL: 6.2)], [11],[26]\}

\begin{tabular}{|c|c|c|c|c|c|}
\hline Type & $\begin{array}{c}\text { Diameter } \\
\text { of bar } \\
(\mathrm{mm})\end{array}$ & $\begin{array}{c}\text { Yield } \\
\text { stress }\left(\mathrm{f}_{\mathrm{y}}\right)\end{array}$ & $\begin{array}{c}\text { Elasticity } \\
\text { modulus } \\
\left(\mathrm{E}_{\mathrm{s}}\right) \\
\mathrm{N} / \mathrm{mm}^{2}\end{array}$ & $\begin{array}{c}\text { Tensile } \\
\text { strength }\end{array}$ & $\begin{array}{c}\text { Density } \\
\text { of steel }\end{array}$ \\
\hline $\begin{array}{c}\text { High } \\
\text { yield }\end{array}$ & $\begin{array}{c}12\left(\mathrm{~m} / \mathrm{mm}^{2}\right. \\
\text { Bar })\end{array}$ & 415 & 200,000 & 485 & 7850 \\
$\begin{array}{c}\text { Steel } \\
(\text { Fe } 415)\end{array}$ & $\mathrm{kg} / \mathrm{m}^{3}$ \\
\hline $\begin{array}{c}\text { High } \\
\text { yield } \\
\text { Steel } \\
(\text { Fe 415) }\end{array}$ & $\begin{array}{c}\text { 8(Stirrups } \\
\text { and } \\
\text { Hanger } \\
\text { Bar })\end{array}$ & 415 & 200,000 & 485 & 7850 \\
\hline
\end{tabular}

Table-6: Steel bar reinforcement properties \{IS: 456-200(CL 5.6.3)],[ IS :1786 - 1985], [10]\}

\begin{tabular}{|c|c|c|c|c|}
\hline Type & $\begin{array}{c}\text { Compressive } \\
\text { Strength } \\
\left(\mathrm{f}_{\mathrm{ck}}\right) \\
\mathrm{N} / \mathrm{mm}^{2}\end{array}$ & $\begin{array}{c}\text { Flexural } \\
\text { Strength } \\
\left(\mathrm{f}_{\mathrm{cr}}\right) \\
\mathrm{N} / \mathrm{mm}^{2}\end{array}$ & $\begin{array}{c}\text { Elasticity } \\
\text { modulus } \\
\left(\mathrm{E}_{\mathrm{c}}\right) \\
\mathrm{N} / \mathrm{mm}^{2}\end{array}$ & $\begin{array}{c}\text { Density } \\
\text { of } \\
\text { concrete } \\
\mathrm{kg} / \mathrm{m}^{3}\end{array}$ \\
\hline $\begin{array}{c}\text { Plain } \\
\text { concrete }\end{array}$ & 25 & 3.5 & 25,000 & 2400 \\
\hline
\end{tabular}

Table-7: Steel Fiber Properties [12]

\begin{tabular}{|c|c|c|c|c|}
\hline $\begin{array}{c}\text { Material } \\
\text { types }\end{array}$ & $\begin{array}{c}\text { Elastic } \\
\text { modulus } \\
(\mathrm{GPa})\end{array}$ & $\begin{array}{c}\text { Average } \\
\text { Strength } \\
(\mathrm{MPa})\end{array}$ & Homogeneity & $\begin{array}{c}\text { Poisson's } \\
\text { Ratio }\end{array}$ \\
\hline $\begin{array}{c}\text { Steel } \\
\text { fiber }\end{array}$ & 200 & 828 & 10 & 0.3 \\
\hline
\end{tabular}

\section{TEST MATERIALS}

\subsection{Cement}

Portland Pozzolana Cement as per IS: 1489(part 1)-1991has been used throughout the investigation. The properties of cement have been found from the laboratory test are Fineness $(90 \mu$ Sieve $)=5 \%$, Normal consistency $=34 \%$, Initial $\&$ Final setting time $=75$ minute $\& 216$ minute respectively and 28 days Compressive strength $=55.63 \mathrm{MPa}$.

\subsection{Fine Aggregate}

Natural River sand having specific gravity of 2.63, fineness modulus of 3.28 and water absorption of $2.21 \%$ has been used. The sand also conforms to the grading zone III as per (IS: 383-1970) Indian Standard specifications.

\subsection{Coarse Aggregate}

Well graded aggregate, obtained using locally available crushed stone aggregates of $12.5 \mathrm{~mm}$ size with fineness modulus of 5.82 and $10 \mathrm{~mm}$ size with fineness modulus of 3.861 having specific gravity of 2.85 , have been used throughout the investigation. Water absorptions have been found to be $2.13 \%$ and $2.21 \%$ for $12.5 \mathrm{~mm}$ and $10 \mathrm{~mm}$ aggregates respectively.

\subsection{Water}

Portable water free from any harmful amounts of oils, alkalis, sugars, salts and organic materials has been used for mix proportioning and curing of the RC specimens.

\subsection{Steel Fiber}

The steel fibers used in the present study were round and straight fibers. The diameter and length of the fibers were $\mathrm{d}_{\mathrm{f}}=0.7 \mathrm{~mm}$ and $\mathrm{l}_{\mathrm{f}}=28 \mathrm{~mm}$, respectively, and, thus, the aspect ratio was 40 . The volume of steel fiber has been used in the concrete mixes is $1 \%$ of the total volume of the demarcated concrete throughout the investigation.

\subsection{Tension Reinforcement}

$12 \mathrm{~mm}$ diameter bars were used as tension reinforcement whose yield strength was $415 \mathrm{MPa}$.

\subsection{Mix Design}

The high strength concrete mix design was done using IS: 10262-2009. By conducting trial mixes and making suitable adjustments in the mix proportion for good slump and requisite strength, the following mix proportion has finally been arrived at as shown in Table- 8 .

Table-8: Mix Proportion of Concrete

\begin{tabular}{|c|c|c|c|c|}
\hline Content & Water & Cement & F.A. & C.A. \\
\hline$(\mathrm{kg})$ & 197 & 394 & 641.93 & 1236.67 \\
\hline Ratio & 0.5 & 1.0 & 1.629 & 3.13 \\
\hline
\end{tabular}

\section{BEAM DETAILS AND TESTING}

\subsection{Beam Designation}

A total of four sets of experiments each having three concrete beams, one set control beam and three sets with randomly distributed discrete steel fiber at different depths henceforth noted as fiber reinforced concrete (FRC) beam. These beams are designated as shown Tables 1, 2, 3 and 4 for control beam, fully fiber reinforced concrete beam, half depth level fiber reinforced concrete beam and fiber reinforced up to top level of tensile reinforced zone respectively. On the other hand, Figs. 2 to 5 represent the sectional view of still fiber level of such beam specimens respectively. 


\subsection{Test Procedure}

The beams were tested under two point loading on $1000 \mathrm{kN}$ loading frame. The test specimen was simply supported on rigid supports. Two point loads were applied through a rigid spread beam. The specimen was loaded using a $1000 \mathrm{kN}$ jack which has a $1000 \mathrm{kN}$ load cell to monitor the load. The loading were performed through displacement control with a rate of $0.04 \mathrm{~mm} / \mathrm{sec}$. Based on the shear span, the support of the spread beam was adjusted. A linear voltage differential transducer (LVDT) was used to measure the vertical deflection at mid-span and under the load points. The test process was monitored on a computer screen, and all load and deformation data were recorded and stored in a diskette via a data logger. At the end of every $20 \mathrm{kN}$ load increment, observations and measurements were recorded for the crack development and propagation on the beam surfaces. Three LVDTs were provided, one at the center of the span and others under the loading point positions to measure deflections. The load and deflections were monitored and recorded for every 4 seconds. The load at which the diagonal crack and the ultimate shear crack developed was also recorded. Crack patterns were marked on the beams. The test set-up is presented in Fig.7.
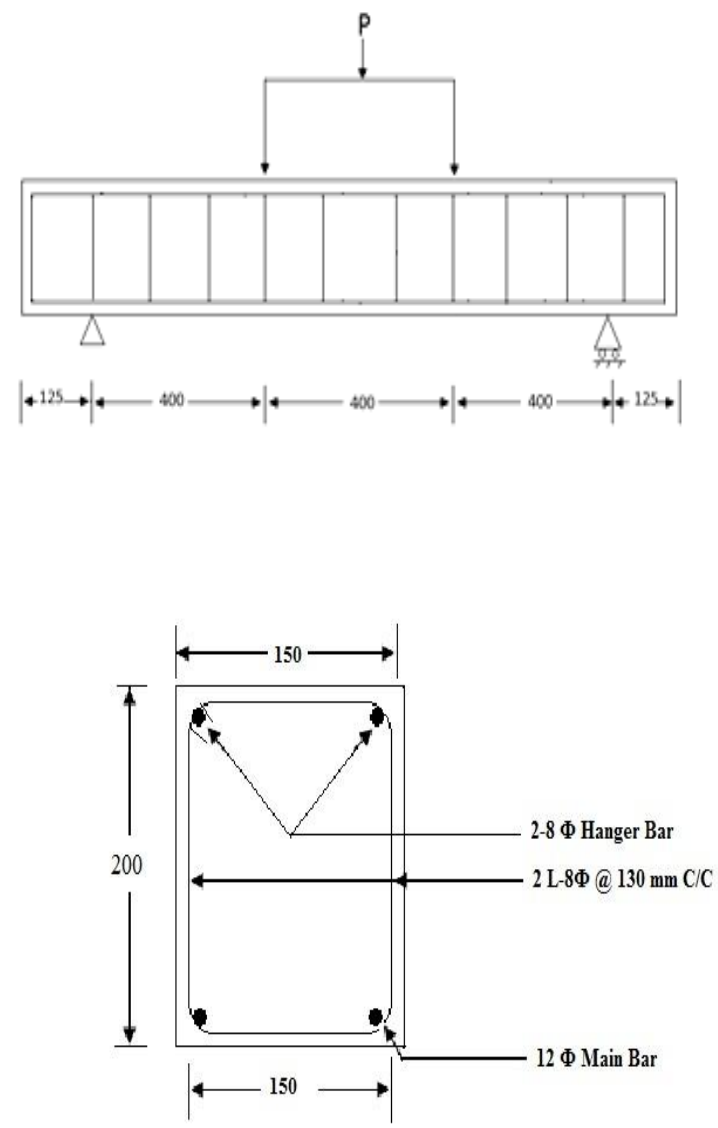

BEAM SECTION A-B

Fig.-6: Details of Test Beams with arrangement of Loads and Supports

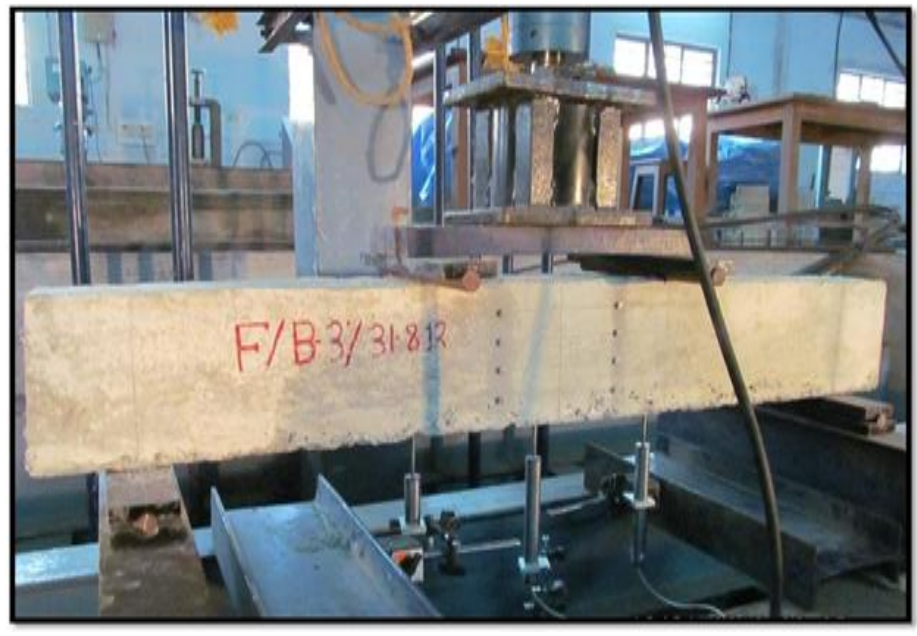

Fig.-7: Beam and LVDT arrangement in 1000 kN Loading Frame

\section{RESULTS AND DISCUSSION}

\subsection{Ultimate Load and Modes of Failure}

The development and propagation of cracks were recorded on the surface of specimens during the test as shown in Figs. $8,9,10$, and 11 . The first crack due to flexure occurred at the mid-span region when the applied load reached 10-40\% of ultimate load and thereafter the cracks were propagated up to mid-depth of beam section. The diagonal crack appeared as the applied load reached $40-80 \%$ of ultimate load and propagated rapidly in shear span region. Most of the beam specimens failed finally through flexure-shear cracking and in few cases (mainly for fully fiber beams) were shown the flexure failure trend.

It is well known that the shear span-to-depth $(\mathrm{a} / \mathrm{d})$ ratios of specimens affect the crack development and failure modes. But it was observed that due to the use of steel fiber reinforcement at different depth level of the beams, shear compression failure mode occurred in these specimens. Similar observations were also made for the controlled beam specimens.

It was observed from Fig.8 for the Reinforced Concrete Beam (i.e. control beams) that in the region of the mid span, flexure-shear cracks were initiated from the bottom level of such beams at a load approximately $150 \mathrm{kN}$ and propagated with increase in load; whereas the shear cracks started appearing at a load of approximately $350 \mathrm{kN}$ and continued to propagate and widened with the elevated load till the final failure occurred at on an average load of $710 \mathrm{kN}$. The mode of failure was observed to be shear crushing of the concrete. 


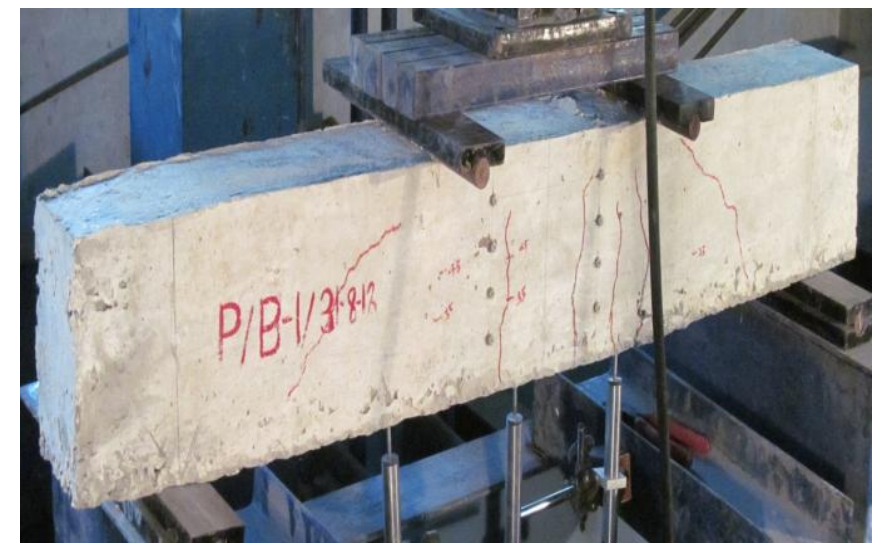

Fig.-8: The crack patterns of Reinforced Concrete Beam (i.e. control beams) Specimens

For specimen F/B-3 which was fully steel fiber reinforced with stirrups, no cracks were visible on the sides of the beam until $200 \mathrm{kN}$ load was reached. On the other hand, diagonal shear crack was observed near the middle of shear spans when the applied load reached at $300 \mathrm{kN}$ level. Finally, the beam failed at a load of $850 \mathrm{kN}$. It was observed for the fully fiber reinforced concrete beams that in the region of the mid span, flexure cracks were initiated from the bottom level of such beams at a load of approximately $350 \mathrm{kN}$ and further propagated with increased load. It is evident for the test results (vide Table- 9) that there was an average increase of $20 \%$ in ultimate load capacity of fully FRC beam specimens as compared to control beam specimens. The mode of failure was observed to be shear compression of such beam specimens.

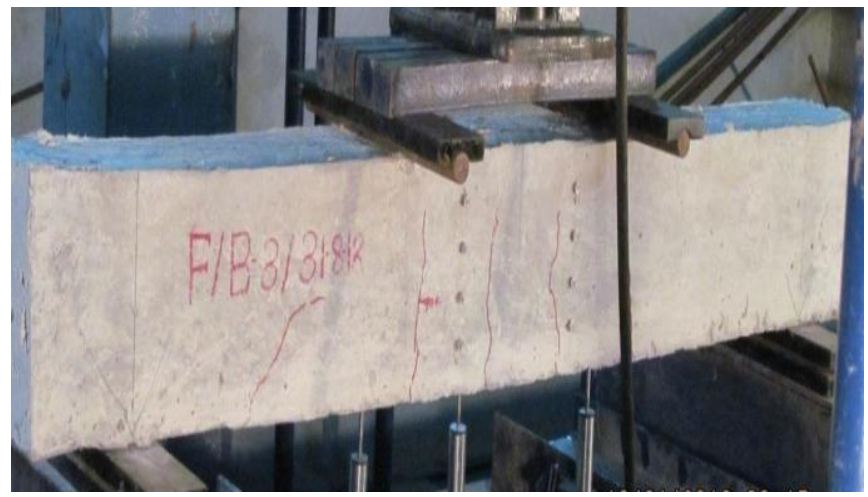

Fig.-9: The crack patterns of Fully Fiber RC Beam Specimens

For specimen $0.5 \mathrm{D}-\mathrm{B}-3$, which was reinforced with steel fiber up to half depth of the beam along with stirrups, the first crack was occurred at $250 \mathrm{kN}$ at the bottom mid span of the beam. This beam exhibited the first crack at a higher load than the control beam P/B-1 $(150 \mathrm{kN})$ due to the presence of the steel fiber. It was observed for specimens reinforced with steel fiber up to half depth of the beam that in the region of the mid span, flexure-shear cracks were initiated from the bottom level and continues to propagate with increased load. The corresponding failure load occurred at $750 \mathrm{kN}$. The enhancement of the failure load was observed which is of the order of average $6 \%$ higher in comparison to that of the control beam. The mode of failure was observed to be shear compression of such specimens

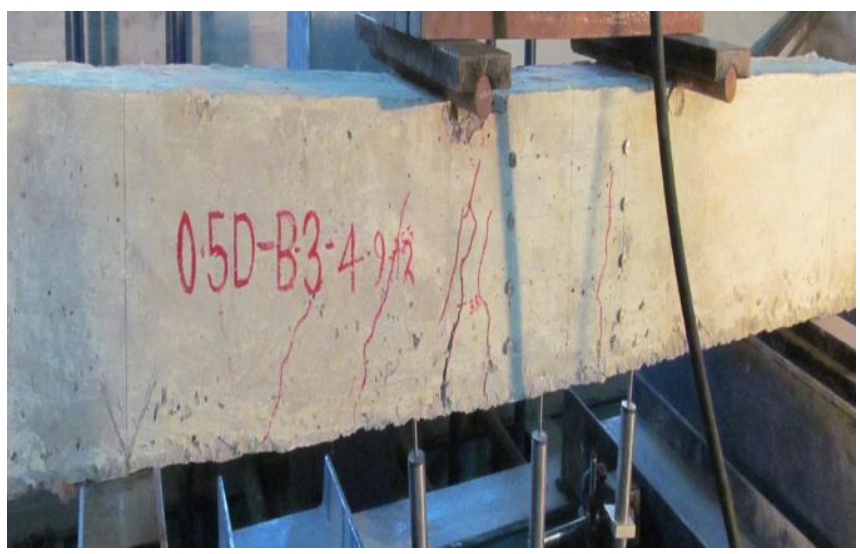

Fig.-10: The Crack Patterns of 0.5 Depth Level of Fiber RC beam Specimens

On the other hand, for the TL.SB(F)-B-3 which was used with steel fiber reinforced up to top level of main reinforcement bar with stirrups, the first crack was seen at $200 \mathrm{kN}$ load level at the bottom mid span of the beam . It was also observed for this beam that in the region of the mid span, flexure shear cracks were initiated from the bottom level of such beams at a load of approximately $248 \mathrm{kN}$ and continue to propagate with increasing load. While the ultimate load was recorded as $730 \mathrm{kN}$ with $4 \%$ average increase in load capacity over and above the control beam P/B-1. Shear compression mode of failure was observed for such types of beam specimens.

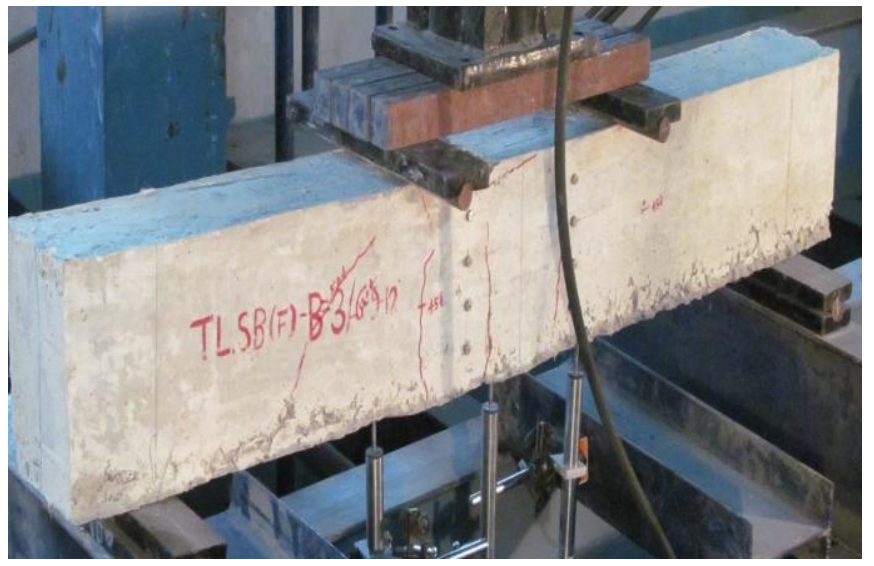

Fig.-11: The Crack Patterns of Tensile bar Depth Level of Fiber RC Beam Specimens 
Table-9: Experimental Results

\begin{tabular}{|c|c|c|c|c|c|c|}
\hline Specimen & $\begin{array}{c}\text { Beam } \\
\text { Designation }\end{array}$ & $\begin{array}{l}\text { First Crack load } \\
\qquad(k N)\end{array}$ & $\begin{array}{l}\text { Ultimate load } \\
(\mathrm{kN})\end{array}$ & $\begin{array}{c}\text { Shear Force } \\
(\mathbf{k N})\end{array}$ & $\begin{array}{c}\text { Max Mid } \\
\text { Deflection } \\
(\mathbf{m m})\end{array}$ & Mode of failure \\
\hline \multirow{3}{*}{$\begin{array}{l}\text { Reinforced } \\
\text { concrete beam }\end{array}$} & P/B-1 & 150 & 720 & 360 & 16 & Shear compression \\
\hline & $\mathrm{P} / \mathrm{B}-2$ & 145 & 710 & 355 & 16 & Shear compression \\
\hline & P/B-3 & 150 & 700 & 350 & 15 & Shear compression \\
\hline \multirow{3}{*}{$\begin{array}{l}\text { Fiber reinforced } \\
\text { concrete beam }\end{array}$} & F/B-1 & 310 & 830 & 415 & 13 & Shear compression \\
\hline & F/B-2 & 300 & 820 & 410 & 12 & Shear compression \\
\hline & F/B-3 & 320 & 840 & 420 & 14 & Shear compression \\
\hline \multirow{3}{*}{$\begin{array}{l}0.5 \mathrm{D} \text { depth of } \\
\text { Fiber level, } \\
\text { reinforced } \\
\text { concrete beam }\end{array}$} & $0.5 \mathrm{D}-\mathrm{B}-1$ & 260 & 740 & 370 & 13 & Shear compression \\
\hline & $0.5 \mathrm{D}-\mathrm{B}-2$ & 260 & 770 & 385 & 13 & Shear compression \\
\hline & $0.5 \mathrm{D}-\mathrm{B}-3$ & 250 & 750 & 375 & 14 & Shear compression \\
\hline \multirow{3}{*}{$\begin{array}{l}\text { The Depth of } \\
\text { fiber up to top } \\
\text { level of tensile } \\
\text { reinforcement } \\
\text { Bar, reinforced } \\
\text { concrete beam }\end{array}$} & TL.SB(F)-B-1 & 200 & 720 & 360 & 14 & Shear compression \\
\hline & TL.SB(F)-B-2 & 210 & 730 & 365 & 13 & Shear compression \\
\hline & TL.SB(F)-B-3 & 200 & 740 & 370 & 14 & Shear compression \\
\hline
\end{tabular}

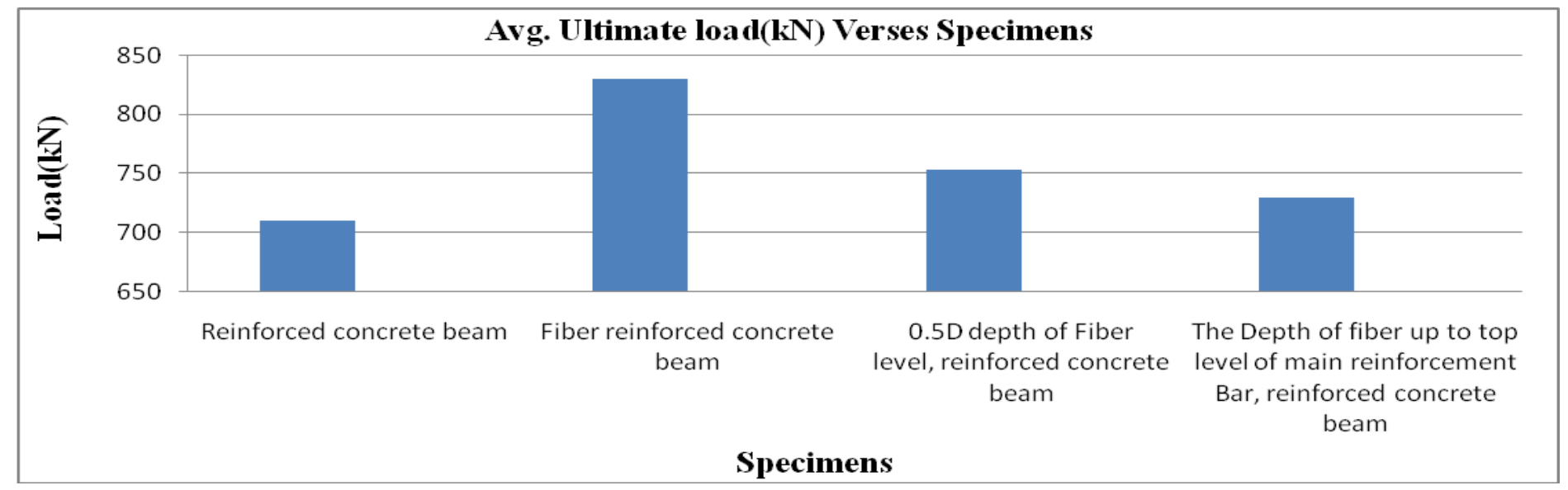

Fig.-12: Average Ultimate load verses Specimens

\subsection{Load Deflection Behaviour}

The load-deflection plots for all the tested beam specimens are as shown in Fig.13, Fig.14 Fig.15.and Fig.16. All the steel fiber incorporated beam specimens showed better load deflection characteristics than the control beam specimens. It is also observed that all the beam specimens incorporated with steel fiber exhibit linear behavior comparatively at higher load level before the appearance of the first crack. These has significantly enhanced the strength capacity and increased the ultimate load of damaged beams and have given better performance in comparison to the controlled plain reinforced beams. 


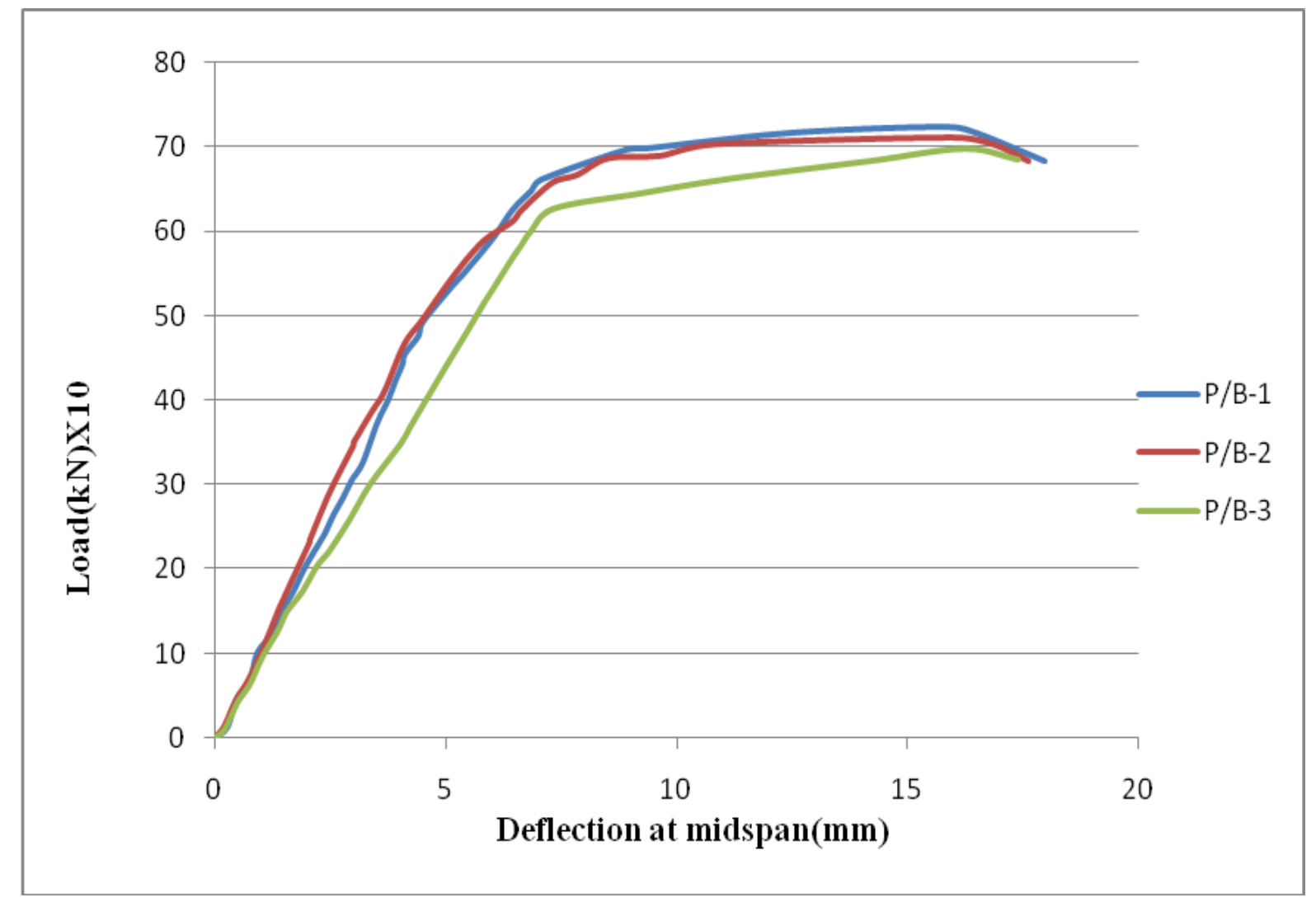

Fig.-13: Load deflection plot of beam specimens in Reinforced Concrete Beam

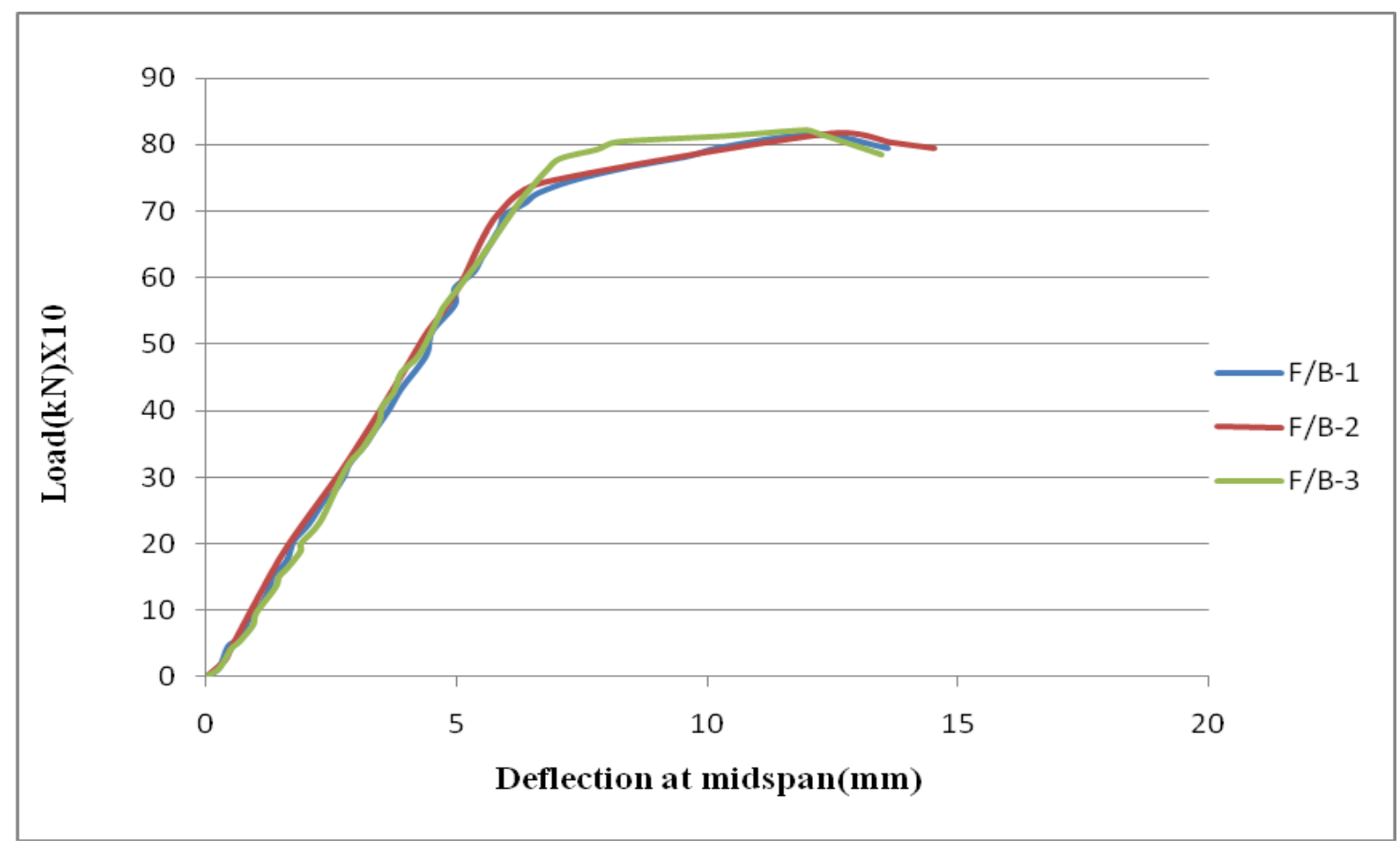

Fig.-14: Load Deflection Plot of Fully Fiber Concrete Beam Specimens 


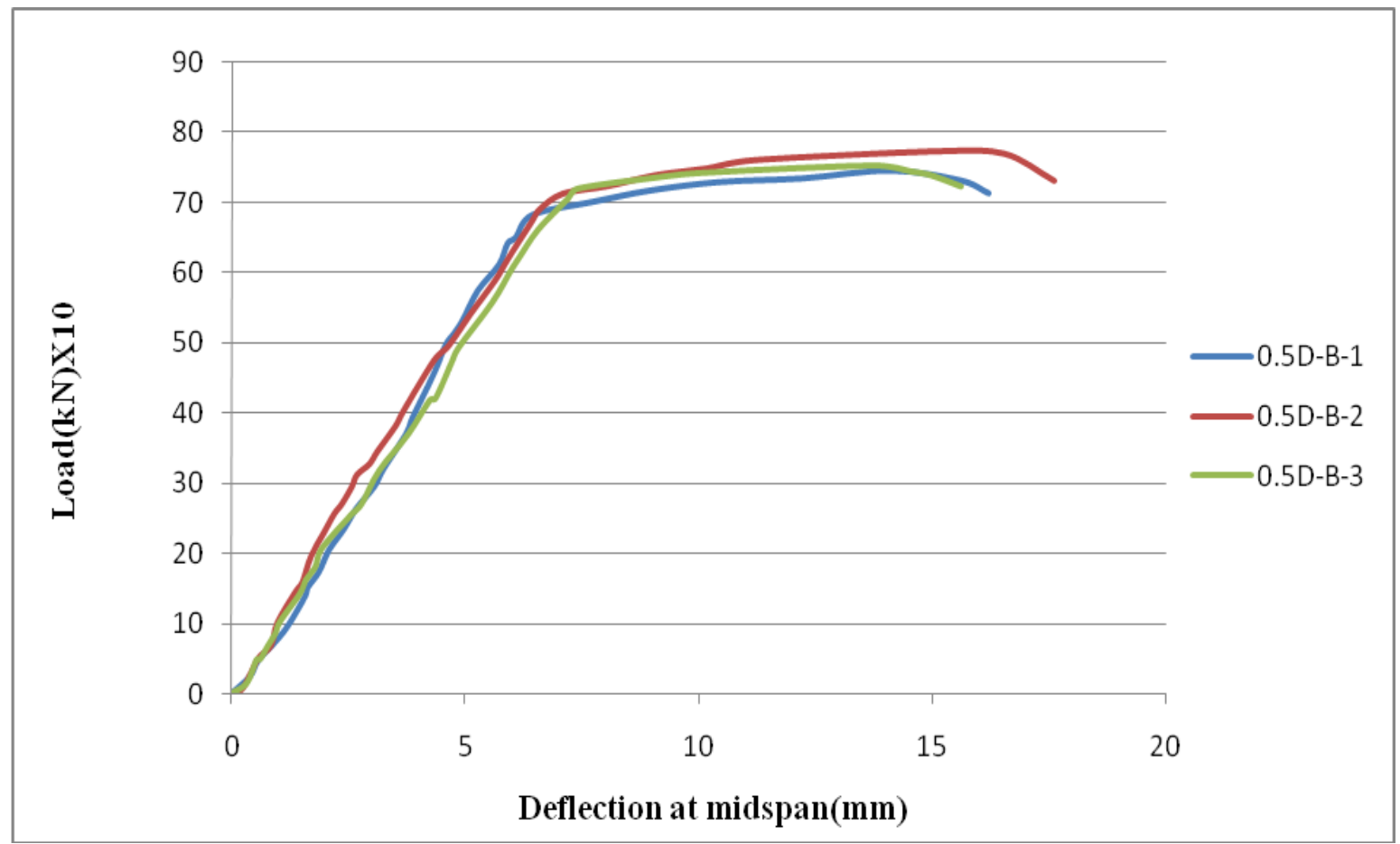

Fig.-15: Load Deflection Plot of 0.5 Depth Level of Fiber RC beam Specimens

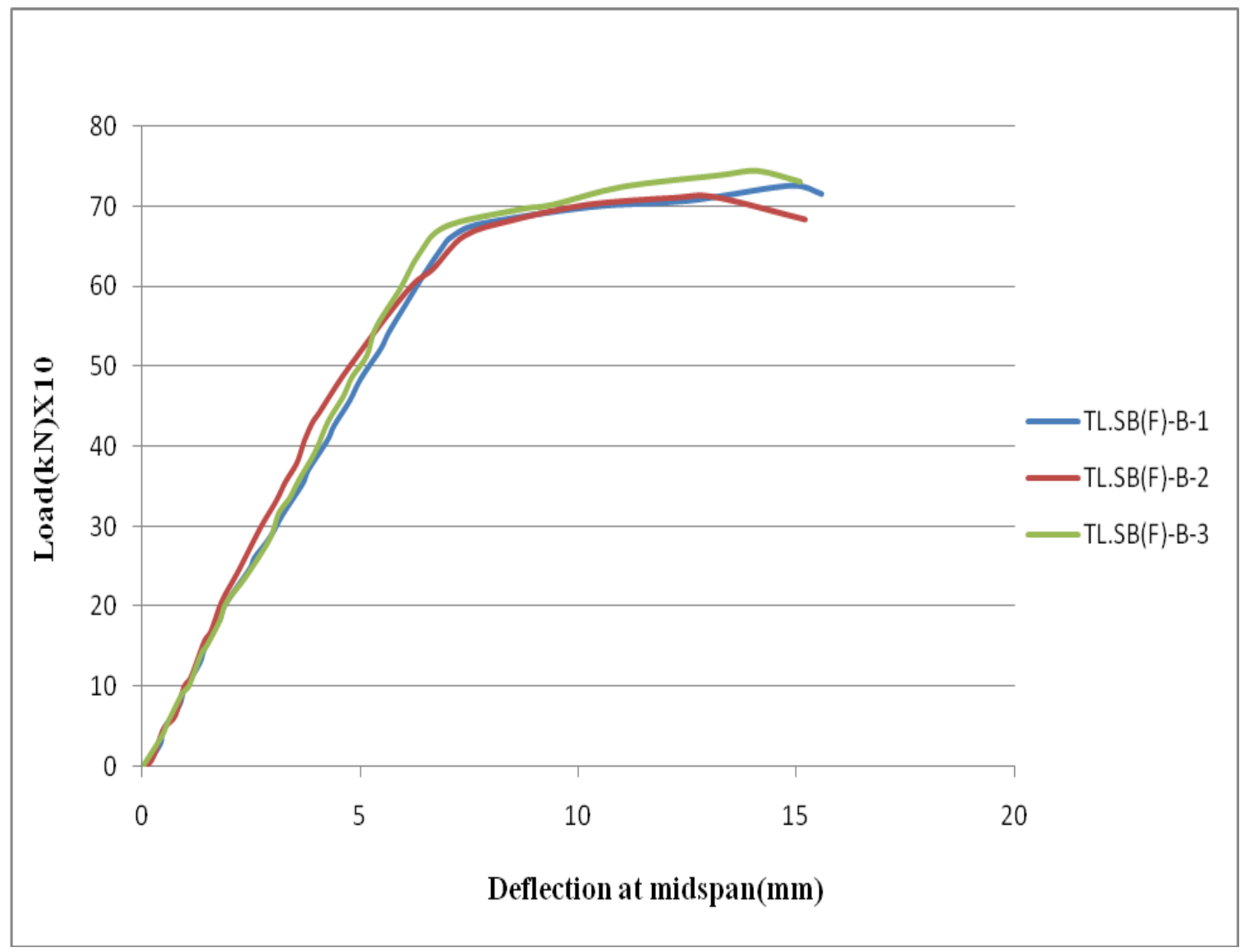

Fig.-16: Load Deflection Plot of Top Level of Tensile Steel Bar of Fiber RC Beam Specimens 


\section{CONCLUSIONS}

From the study conducted on the strengthening of concrete beams using Steel Fiber at different depth of the beam; the following conclusions were drawn:

1. Steel fibers reinforcement, main reinforcement and stirrups are found to be effective in shear strengthening of concrete beams.

2. The FRC beams of all types have shown improvement in terms of first crack load, ultimate load and deflection characteristics when compared to that of the control beam.

3. The overall performances of all the FRC beams were superior to that of the control beam.

4. The beam specimen incorporated fully with steel fiber reinforcement has exhibited an increase of average $20 \%$ in ultimate load, when compared to the control beam specimens. Whereas the beams incorporated with steel fibers up to half depth and tensile steel bar depth levels have shown enhancement of ultimate load of the order of $4 \%$ to $10 \%$ when compared with those of the control beam specimens.

5. The ultimate shear and bending capacities of all the FRC beams were more than that of the control beam specimens. The FRC beam specimens reinforced with fully steel fiber have attained an increase of $20 \%$ in the shear capacity, when compared to the control beam specimens.

6. All types of FRC beam specimens have shown better load deflection characteristics than the control beam specimens. For any particular load, the deflection of all such beam specimens was lower than that of the control beam specimens.

7. Shear compression failure mode have been observed for all types of beam specimens irrespective of steel fiber incorporation in such specimens. The flexural crack has been seen only for the fully FRC beam specimens.

\section{REFERENCES:}

[1].A. Bentur, \& S.Mindess, "Fibre Reinforced Cementitious Composites.”,(Elsevier Science Publishers Ltd, 1990), London.

[2].S.P. Shah \& C.Ouyang, "Mechanical behavior of fiber -reinforced cement -based composite.", Journal of the American Ceramic Society, Vol. 74, Issue 11, pp. 22272953, (1991).

[3]. Dr.A.M.Pande, ER. Prashant Y.Pawade, "Effect of Steel Fibers on Modulus of Elasticity of concrete.", IJAEST Vol. 7, Issue 2, pp. 169 - 177, (2011).

[4].Eduardo N. B. Pereira, Joaquim A.O.Barros and Aires Camões, "Steel Fiber - Reinforced Self - Compacting Concrete", Experimental Research and Numerical
Simulation,Journal of Structural Engineering, Vol. 134, Issue 8, pp.1310-1321, (2008).

[ 5]. M. T. Kazemi, F. Fazileh, and M. A. Ebrahiminezhad, "Cohesive Crack Model and Fracture Energy of Steel-FiberReinforced-Concrete Notched Cylindrical Specimens" Journal of Material in Civil Engineering, Vol. 19, Issue 10, pp.884-890, (2007).

[6]. H. V. Dwarakanath and T. S. Nagaraj.Deformational,

"Behavior of Reinforced Fiber Reinforced Concrete Beams in Bending," Journal of Structural Engineering, Vol. 118, Issue 10, pp.2691-2698, (1992).

[7].Job Thomas and Ananth Ramaswamy. "Mechanical Properties of Steel Fiber-Reinforced Concrete.", Journal of Material in Civil Engineering, Vol. 19, Issue 5, pp.385-392, (2007).

[8]. Hehua Zhu et al., "Numerical Analysis and Field Test on Performance of Steel Fibre Reinforced Concrete Segment in Subway Tunnel", Proceedings of Sessions of Geo Shanghai, Editors Shanghai, China, (2006).

[9]. L. G. Sorelli, A. Meda, and G. A. Plizzari. ,"Bending and Uniaxial Tensile Tests on Concrete Reinforced with Hybrid Steel Fibers.", Journal of Material in Civil Engineering, Vol. 17, Issue 5, pp.519-527, (2005).

[10].Glenn Elert, "Topic 3.5b Stress probs2 ( Determinate). www. hypertextbook. Com /facts /2004/Karen Suther land shtml, University of Wisconsin-Stout Physics Department, (1998).

[11].McGraw-Hill, "Encyclopedia of Science and Technology", www. amazon. Com, the sixth edition, Vol.1,ISBN 978-0-07-161366-8, (2009).

[12]. R.S. Londhe,"Experimental Investigation on Shear Strength of SFRC Beams Reinforced with Longitudinal Tension Steel Rebars" Asian Journal of Civil Engineering (Building and Housing) Vol. 11, Issue 3, pp. 385-395, (2010).

[13].Anette jansson, "Fibers in reinforced concrete structures -analysis, experiments and design" www. publications. lib. chalmers.se/records/ fulltext / 68889.pdf, Department of Civil and Environmental Engineering, Division of Structural Engineering Chalmers University of Technology, Göteborg, Sweden, ISSN 1652-9146, (2008).

[14]. C.Q. Fu, X.Y. Jin, N.G. Jin, "Numerical Experiment on Flexural Properties of Steel Fiber Reinforced Concrete Beam," WRI World Congress on Computer Science and Information Engineering, csie, Vol. 7, pp.755-759,( 2009).

[15].M.Barbato, "Efficient finite element modelling of reinforced concrete beams retrofitted with fibre reinforced polymers.",Department of Civil and Environmental Engineering, Louisiana State University, USA, Vol. 87, Issue 3-4, (2009).

[16]. Padmanabha Rao Tedepalli,Y .L.MO,Thomas T.C.Hsu and John Vogel ,"Mechanical Properties of steel Fiber Reinforced Concrete Beams.” ,Structures Congress, pp. 110, (2009).

[17]. Sydney Furlan Jr and Joao Bento de Hanai, "Shear behaviour of fiber reinforced concrete beams.", Elsevier (Cement and Concrete Composite) Vol.19, Issue No 4, pp.359-366, (1997). 
[18]. Sudheer Reddy.L , Ramana Rao .N.V, Gunneswara Rao T.D., "Shear Resistance of High Strength Concrete Beams Without Shear Reinforcement.", International Journal of Civil and Structural Engineering, Vol.1, Issue 1, (2010).

[19].Yasmeen Taleb Obaidat, "Using Carbon Fiber Reinforced Polymer." www. byggmek. lth.se / fileadmin / byggnadsmekanik /web3070.pdf, Copyright (C) 2010 by Structural Mechanics, LTH, Sweden.Printed by Wallin \& Dalholm Digital AB, Lund, Sweden, (Pl) (2010).

[20].Obaidat, Y.T., Heyden, S., Dahlblom, O., Abu-Farsakh, G., and Abdel-Jawad, Y."Retrofitting of reinforced concrete beams using composite laminates "Submitted to Construction \& Building Materials, vol. 25, Issue 2, (2010).

[21]. Nabil Mohamed EmhdaB alnatit, "Computational Study on Shear Strengthening of RC Continuous Beams Using CFRP Sheet." https: // eprints. uthm. edu. My / 1751 /1/nabil_mohamed2.pdf, Faculty of Civil and Environmental Engineering University Tun Hussein On Malaysia (UTHM), pp. 1-79, (2011).

[22]. R.Santhakumar,E.Chandrasekaran and R.Dhanaraj, "Analysis of Retrofitted Reinforced Concrete Shear Beams using Carbon Fiber Composites" Dept. of Civil Engg. and Aeronautical Engg., Crescent Engg. College and MIT, Anna University, India. Vol. 123, Issue 7, (2004).

[23].S. Deepa Raj and R.S. Surumi, "Shear Strengthening of Reinforced concrete Beams Using Near Surface Mounted Glass Fibre Reinforced Polymer" Asian Journal of Civil Engineering(Building and Housing), Vol. 13, Issue 5, pp. 679-690, (2012).

[24]. Dat Duthinh and Monica Starnes, "Strengthening of Reinforced Concrete Beams with Carbon fiber FRP.", Journal of composite in Construction, pp. 493-498, (2001).

[25].IS:383-1970, Specification for Coarse and Fine Aggregate from Natural Sources for Concrete, BIS, New Delhi, India.

[26]. IS: 2386 Part III-1963, Methods of test for Aggregates for Concrete, BIS, New Delhi, India.

[27]. IS: 456-2000, Plain and Reinforced Concrete-Code of Practice, BIS, New Delhi, India.

[28].IS: 10262-2009, Recommended Guidelines for Concrete Mix Design, BIS, New Delhi, India.

\section{BIOGRAPHIES}

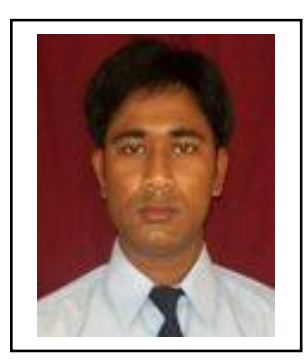

Prakash Mondal, Assistant Professor at the Dept of Civil Engineering, Dr. B. C. Roy Engineering College Durgapur, (W.B.), India. Research interests: Theory of reinforced concrete behaviour, composite structures, strengthening the reinforced concrete structures, behavior of Steel Fiber.

Email:prakashmondalnit@gmail.com

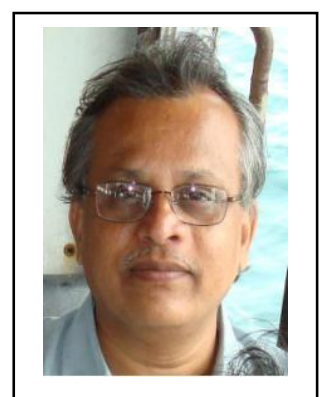

Dilip Kumar Singha Roy, Professor at the Dept of Civil Engineering, National Institute of Technology Durgapur, WestBengal, India. Research interests: Structural Engineering - Comp. and Exp. Mechanics Of Concrete and Composite Structures and Materials, Retrofitting and Strengthening Of Structural Elements.

E-mail: dsr_rec_dgp@yahoo.com 